\title{
The Increasing Importance of Bilateral Agreements in the Foreign Trade Policy
}

\author{
Zdzisław W. Puślecki ${ }^{1}$ \\ ${ }^{1}$ Department of International Economy, Faculty of Political Science and Journalism, Adam Mickiewicz University, \\ Poznań, Poland \\ Correspondence: Zdzisław W. Puślecki, Full Professor, Doctor of Economic Science (PhD), Department of \\ International Economy, Faculty of Political Science and Journalism, Adam Mickiewicz University, Poznań. ul. \\ Umultowska 89 A, 61-614 Poznań, Poland. Tel: 48-61-829-6568.
}

Received: January 7, 2018

Accepted: January 23, 2018

Online Published: February 7, 2018

doi:10.5430/jms.v9n1p19

URL: https://doi.org/10.5430/jms.v9n1p19

\begin{abstract}
The main aim of the article is indication of the increasing importance of bilateral agreements in the foreign trade policy. The subject of the discussion and theoretical contribution in the undertaken research program is presents new tendencies in international business - the rise of importance of bilateral agreements in foreign trade policy. It is important to underline that a few multinational firms are responsible for a major share of world trade and for the rise of global supply chains. On the one hand, these firms should support regulatory harmonization across different Preferential Trade Agreements (PTAs) in order to lower trade costs. On the other hand, they might also resist harmonization - and encourage certain non-tariff measures - in order to prevent new competitors from entering markets. This may partly explain the persistence of regulatory divergence, and suggests that the political economy of regulatory convergence, especially in the conditions of the rise global supply chains, may be more complex than is sometimes suggested.
\end{abstract}

Keywords: foreign trade policy, bilateral trade agreement, global supply chains, anti-protectionist forces, cooperating on trade policies

\section{Introduction (Note 1)}

International trade during the rise of global supply chains interfaces with many other policy areas, such as macroeconomic policy, intellectual property, environmental protection, health and employment. In some of these policy areas, there are well-developed multilateral regimes, while in other areas multilateral cooperation is more incipient and institutional frameworks are less developed. The fragmented, decentralized and non-hierarchical nature of the international trade system makes the pursuit of coherence particularly challenging, fragmentation has the advantage of allowing for experimentation as different policies can be tested at the bilateral, regional and multilateral levels. A number of institutions and policy processes are in place to enforce better surveillance of exchange rates and reduce global imbalances. However, in the time of the rise of global supply chains the question arises as to whether these will be used to set up a more cooperative system of exchange rates at the international level. The challenge of securing agreement is made more acute by the need to resolve difficult questions during the rise of global supply chains about the effectiveness of different policies and their impact on trading partners, the answers to which depend on a number of factors, such as the technology involved, the characteristics of the sector and the markets at issue.

\section{Materials and Methods}

Methodologically inclusive account breaks new ground in the new political economy models on contemporary foreign trade policy. The article presents new tendencies in the international business, the increasing importance of bilateral agreements in the foreign trade policy. The general theoretical approach will be of broad interest to economists interested in international and institutional questions as well as to political scientists. The main method applied in this research was a method of scientific study. It was used the institutional method, the comparative method and the documentation method. It were applied also the descriptive method. Additionally, it used also, the methods of deductive and inductive forecasting.

\section{Discussion}

\subsection{New Tendencies in International Business}

Countries and producers increasingly specialize in certain stages of production depending on their particular comparative advantage (Krist, 2013); (Jackson, 2013). It is importance and magnitude of this development for 
foreign trade policy. It is also important to underline that transport and energy costs, for instance, are reasons why supply chains remain more regional than global. Krugman (1991) brings increasing returns together with capital and labor migration and transport costs into one model. Krugman's (1991) model has become a workhorse of economic geography and international trade. The model is too complex to explain here but the reasons for that complexity are clear to see - when everything becomes "endogenous" small initial differences can make for big effects. To minimize transport costs, for example, firms want to locate near consumers but consumers want to locate near work. Thus, there are multiple equilibria and at a tipping point the location decisions of a single firm or consumer can snowball into big effects. A related trend also is the new form of regionalism that is sometimes refered as integration process development (Baldwin, 2012).

The differences among firms involved in trade are also important for the future development. The picture that arises from the trade literature and the data is that even if many firms are indirectly involved in trade-related activities, only relatively few are exporting or developed economies. Developing economies importing and these firms tend to be larger and more productive than others (Chart 1, Chart 2, Table 1). Such firms also have a role in technology advancement and in the diffusion of know-how through supply chains.

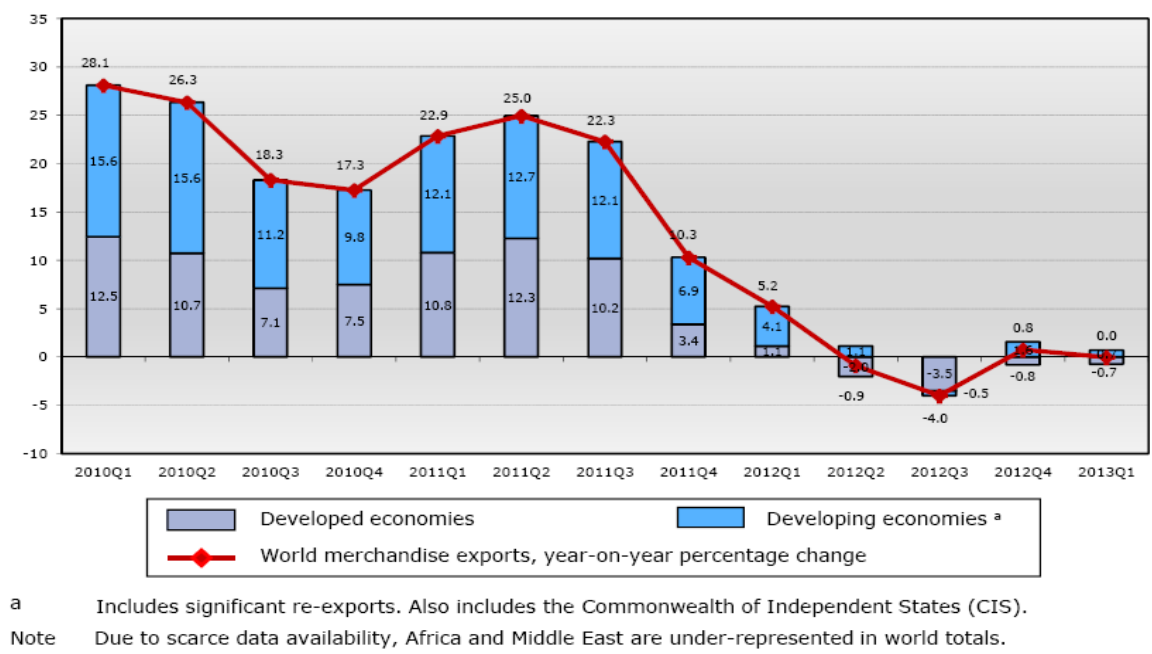

Chart 1. Contributions to year-on-year growth in world merchandise exports, 2010Q1 - 2013Q1

(Percentage change in US\$ values)

Source: WTO Secretariat estimates, based on data compiled from IMF International Financial Statistics; Eurostat Comext Database; Global Trade Atlas; and national statistics. WTO Secretariat 2013.
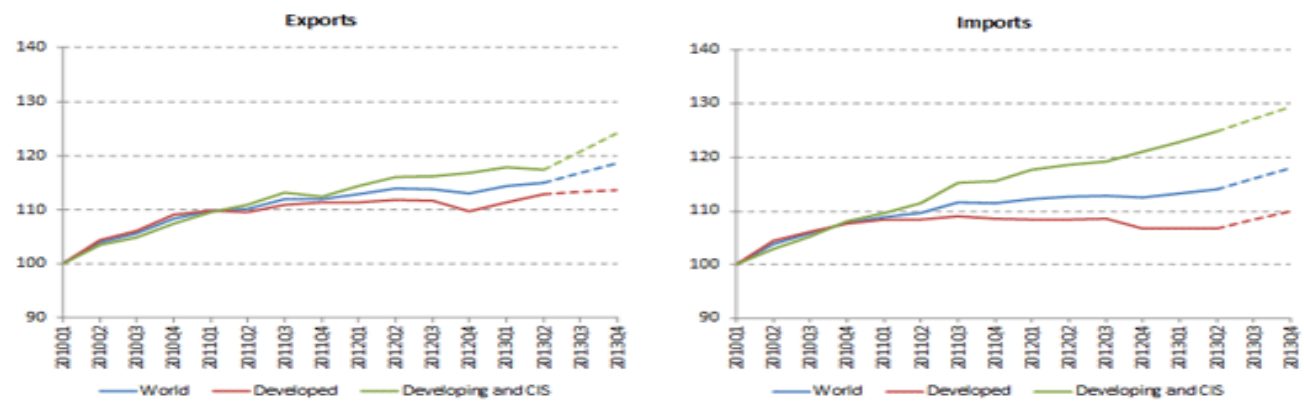

Chart 2. World merchandise trade volume by level of development, 2010Q1-2013Q4 ${ }^{\mathrm{a}}$

Seasonally adjusted indices, 2005Q1 100

${ }^{a}$ Figures for 2013Q3 and 2013Q4 are projections.

Source: WTO Secretariat. http://www.wto.org/english/news_e/pres13_e/pr694_e.htm 24.10.2013 
Table 1 World merchandise trade and GDP, 2009-2014

Annual \% change

\begin{tabular}{|c|c|c|c|c|c|c|}
\hline & 2009 & 2010 & 2011 & 2012 & $2013 P$ & $2014 \mathrm{P}$ \\
\hline Volume of world merchandise trade ${ }^{b}$ & -12.5 & 13.8 & 5.4 & 2.3 & 2.5 & 4.5 \\
\hline \multicolumn{7}{|l|}{ Exports } \\
\hline Developed economies & -15.2 & 13.3 & 5.1 & 1.1 & 1.5 & 2.8 \\
\hline Developing economies and CIS & -7.8 & 15.0 & 5.9 & 3.8 & 3.6 & 6.3 \\
\hline \multicolumn{7}{|l|}{ Imports } \\
\hline Developed economies & -14.3 & 10.7 & 3.2 & 0.0 & -0.1 & 3.2 \\
\hline Developing economies and CIS & -10.6 & 18.2 & 8.1 & 4.9 & 5.8 & 6.2 \\
\hline Real GDP at market exchange rates & -2.4 & 3.8 & 2.4 & 2.0 & 2.0 & 2.6 \\
\hline Developed economies & -3.8 & 2.7 & 1.5 & 1.2 & 1.2 & 1.9 \\
\hline Developing economies and CIS & 2.1 & 7.4 & 5.5 & 4.7 & 4.5 & 4.9 \\
\hline
\end{tabular}

${ }^{a}$ Figures for 2013 and 2014 are projections.

${ }^{\mathrm{b}}$ Average of exports and imports.

Source: WTO Secretariat for trade, consensus estimates of economic forecasters for GDP. http://www.wto.org/english/news_e/pres13_e/pr694_e.htm 24.10.2013

The demand for imports in developing economies is reviving but at a slower rate than expected. This hindered the growth of exports from both developed and developing countries in the first half of 2013 and 2014 was the reason for the lower forecasts. Although the trade slowdown was mostly caused by adverse macro-economic shocks, there are strong indications that protectionism has also played a part and is now taking new forms which are harder to detect. Negotiations under way in the framework of the WTO can address these problems, facilitating greater trade and opportunities to spur economic growth. Some short-term prospects are improving with encouraging data coming from Europe, the US, Japan and China (Chart 3). Reports on private sector activities from purchasing managers (purchasing managers' indices, which give some indication about future activity), shipping rates, automobile production and other leading indicators, suggest that the economic slowdown has bottomed out and that a tentative recovery is underway.

The European sovereign debt crisis has eased significantly since 2012 year, unemployment in the United States has fallen to $7.3 \%$ from a post-crisis high of $10 \%$, and growth of GDP (gross domestic product, a measure of a country's output) in Japan has accelerated since the adoption of new fiscal and monetary policies (Jackson, 2013). Although large developing economies have slowed appreciably, the latest figures from China on industrial production suggest that the country may be regaining some of its dynamism. On the other hand, India's economy is still in the midst of a sharp.

However, both extra-EU imports and trade between EU countries (i.e., intra-EU exports) have declined steadily since the middle of 2011, dropping around 2\% year-on-year in the first half of 2013 (Chart 3). Since the EU (including intra-EU trade) accounts for fully $33 \%$ of world imports and 58\% of developed economy imports, economic shocks there will be strongly reflected in world aggregates.

US exports and imports have been flat since the beginning of 2012, held down by weak external demand and slow growth at home (Chart 3). However, in the second quarter of the 2013 year, exports jumped $2.2 \%$ compared to the previous quarter (9\% when calculated as an annual rate), while imports advanced $1.0 \%$ (4\% annualized), possibly indicating a turning point for US trade flows.

Interesting is also Japan's situation on the export side (Chart 3). The sharp dip in exports in 2011 is linked to the earthquake and tsunami that devastated Japan in that year. The more recent slump beginning in 2012Q3 appears to be related to a diplomatic dispute between Japan and China that has soured trade relations between the two countries. By the second quarter of 2013, Japanese exports were little changed since the beginning of 2010, but imports rose around $20 \%$ over the same interval. Japan's export performance may be erratic, but since it only makes up $4 \%$ of world exports and $9 \%$ of developed economy exports it has less of a direct influence on broad aggregates. 

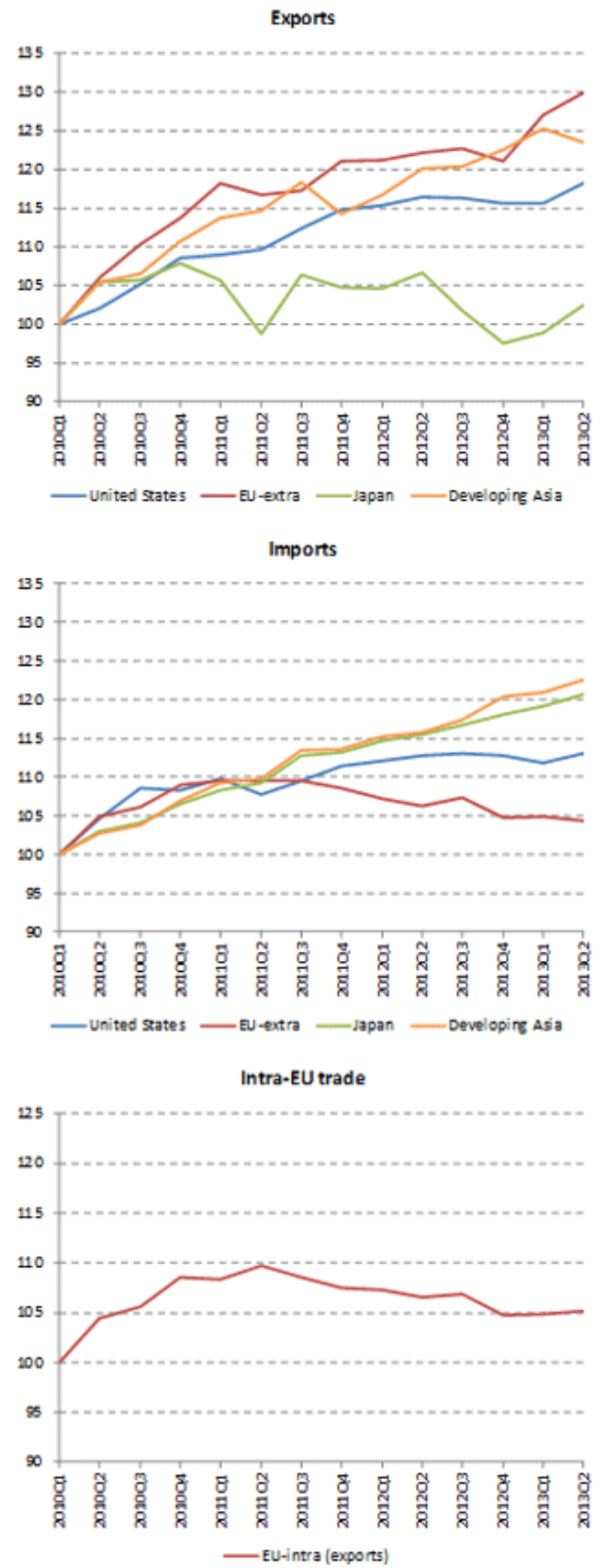

Chart 3. Merchandise exports and imports of selected economies, 2010Q1-2013Q2

Seasonally adjusted volume indices, 2010Q1=100

Source:WTOSecretariat.http://www.wto.org/english/news_e/pres13_e/pr694_e.htm 24.10.2013

Trade flows of developing Asia (which includes China) have maintained a steady pace of growth in recent years, but exports dipped $1.4 \%$ in the second quarter of 2013 compared to the first quarter (5.4\% annualized) (Chart 3). This was due to a relatively sharp drop in China's exports, which could partly be related to weak demand in China's 
trading partners, but could also reflect recent Chinese efforts to correct for misreporting of trade values. However, since trade data are not revised for earlier years, it is unclear whether the drop in the second quarter represents and actual decline in trade flows.

It must be emphasized that openess to trade in China is associated with higher incomes and growth and there are the need for new approaches to trade cooperation in light of the forces that are currently re-shaping international business. A major factor, was the even more remarkable transformation of China, as market reforms opened up its economy to foreign trade and investment, and unleashed an unprecedented growth dynamic that has continued, with only minor slowdowns. In the new circumstances for the development of the global economy and the global trade, People Republic of China seems to be a production superpower, able to change the world trade and influence on the rise of global supply chains. In many areas it possesses comparative advantages. China may continue their development to specialise in electronics and increasingly in services.

It must be underline also the major trend in international trade which is the rise of a number of emerging economies and the associated increase in their shares in world trade (Jackson, 2013). Especially China but also India and Brazil have transformed the balance of power in the multilateral trading system (Jackson, 2013). Between 1980 and 2011, for example, China's share in world merchandise exports and imports increased tenfold, making the country the largest exporter of the world (Jackson, 2013); (Kupchan, 2014).

Finally, Chart 4 shows year-over-year growth in merchandise trade for a wide selection of countries in current US dollar terms. These data are available through June, July or August, 2013 depending on data availability. As such, they can provide an earlier indication of trade developments in the third quarter compared to volume indices, which are generally less timely. It is worth noting that Germany's exports and imports recorded solid increases in June and July, 2013 which could presage a turnaround in EU-wide trade flows.
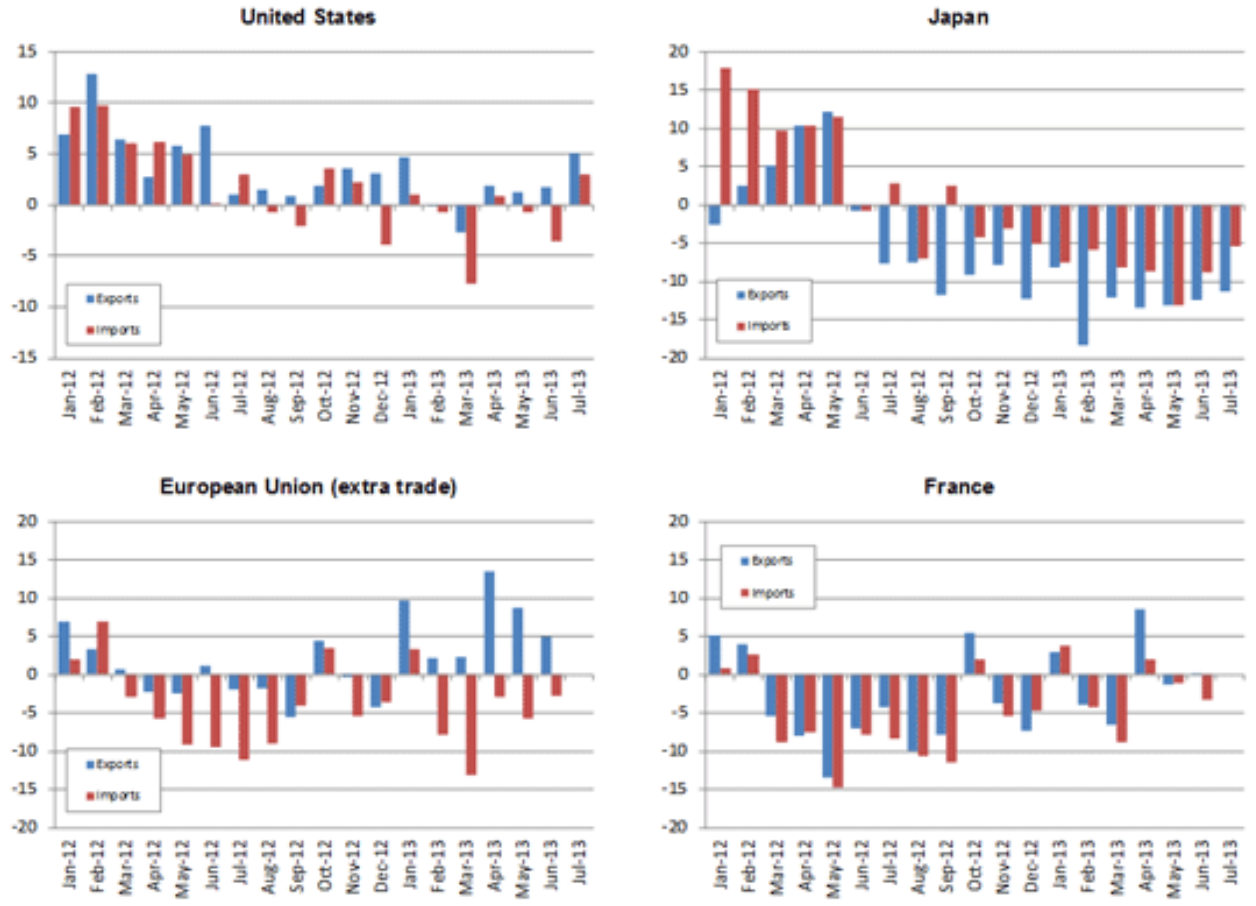

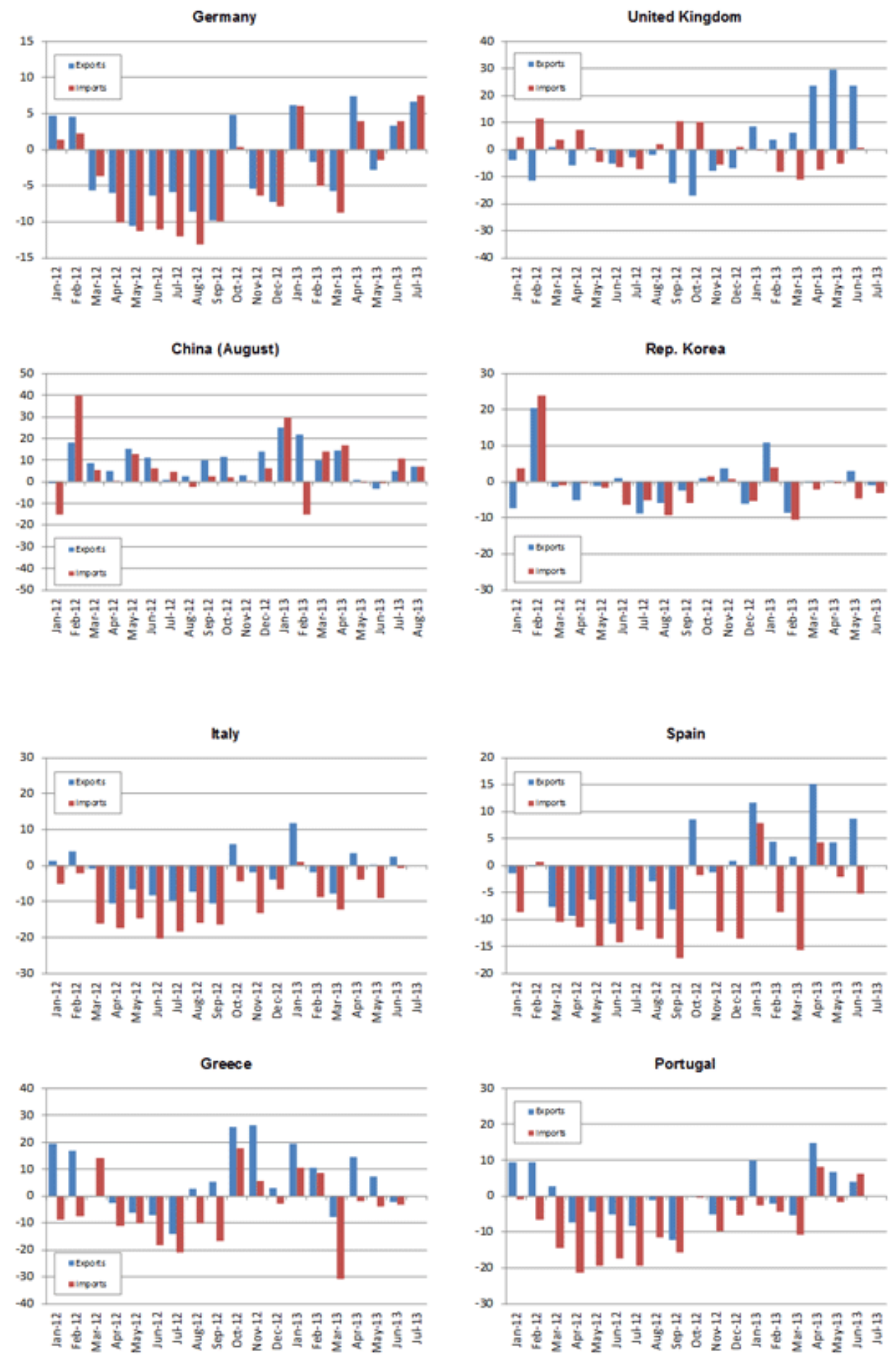

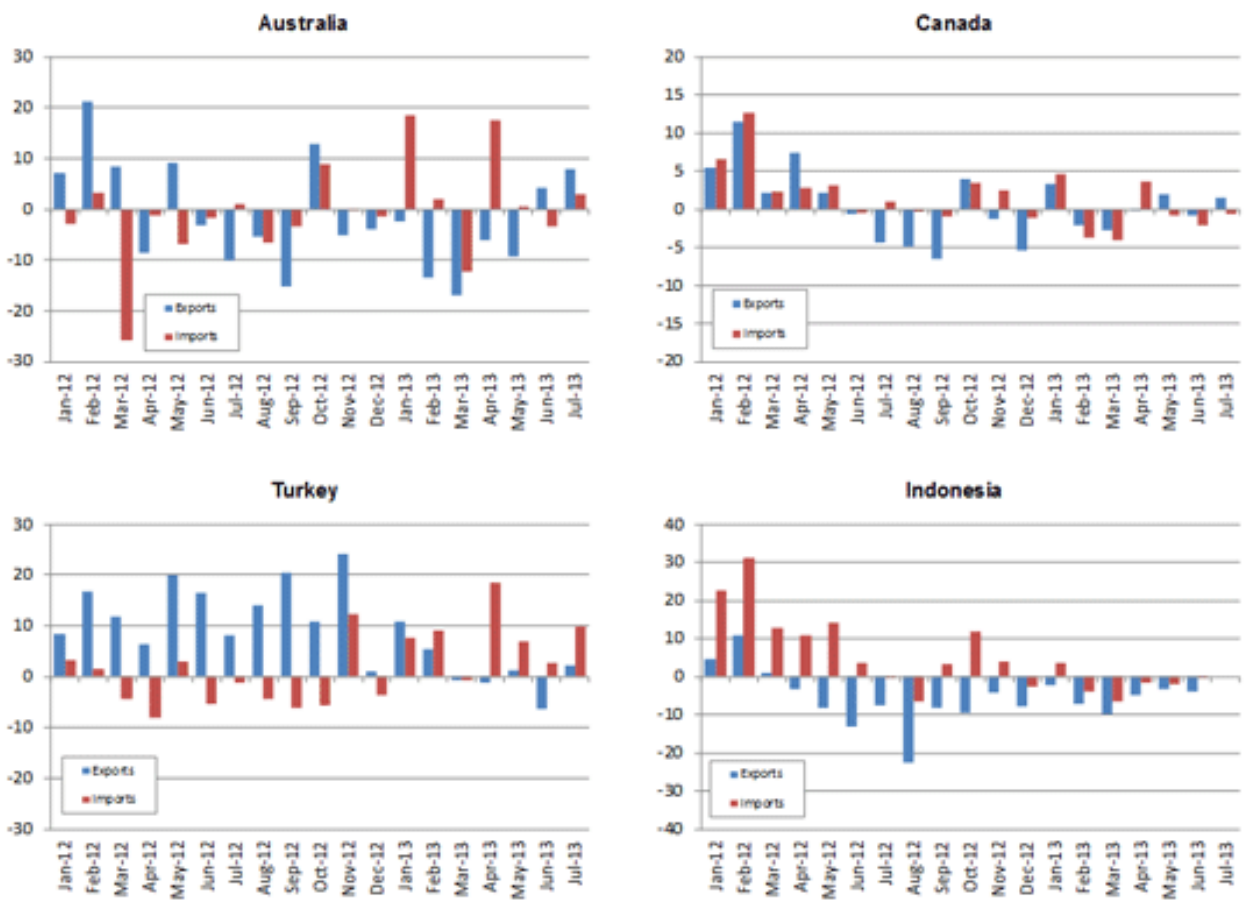

Chart 4. Merchandise exports and imports of selected economies, October 2011-July 2013 Year-on-year \% change in current dollar values

Sources: IMF International Financial Statistics, Global Trade Information Services GTA database, national statistics. http://www.wto.org/english/news_e/pres13_e/pr694_e.htm 24.10.2013

It must be emphasized that although short-term data on trade in commercial services are more limited than existing data sets on merchandise trade, both display similar trends. The recent evolution of this type of trade is illustrated by Chart 5, which shows year-on-year growth in the dollar value of commercial services exports and imports for selected economies from 2012Q1 to 2012Q4. Year-on-year growth in commercial services exports remained positive in the United States throughout 2012 despite a slowdown in the third quarter. However, US services imports were flat in both Q3 and Q4.

The dollar value of Japan's exports of services dropped 5\% year-on-year in 2012Q3, and remained 4\% lower than the previous year's value in Q4. Japan's import growth remained positive in all four quarters of 2012, but had dropped to just $1 \%$ by the fourth quarter. The dollar value of the European Union's commercial services exports declined in the last three quarters of 2012. Meanwhile, growth in services imports was negative in all four quarters. However, the declines in Q4 $(0.3 \%$ for exports, $0.2 \%$ for imports) were barely discernible from zero. Growth in China's exports of commercial services increased from $8 \%$ in Q3 to $10 \%$ in Q4. At the same time, the country's imports of commercial services increased by $17 \%$ in Q4, down from $20 \%$ in Q3. Year-on-year growth rates for India's exports and imports of commercial services diverged strongly in the second half of 2012. Export growth jumped to $13 \%$ in Q3 before settling back to $10 \%$ in Q4. Meanwhile, import growth dropped to just $1 \%$ in Q3 from $7 \%$ in Q2 before contracting by 8\% in Q4 (WT/TPR/OV/W/7, 2013). 

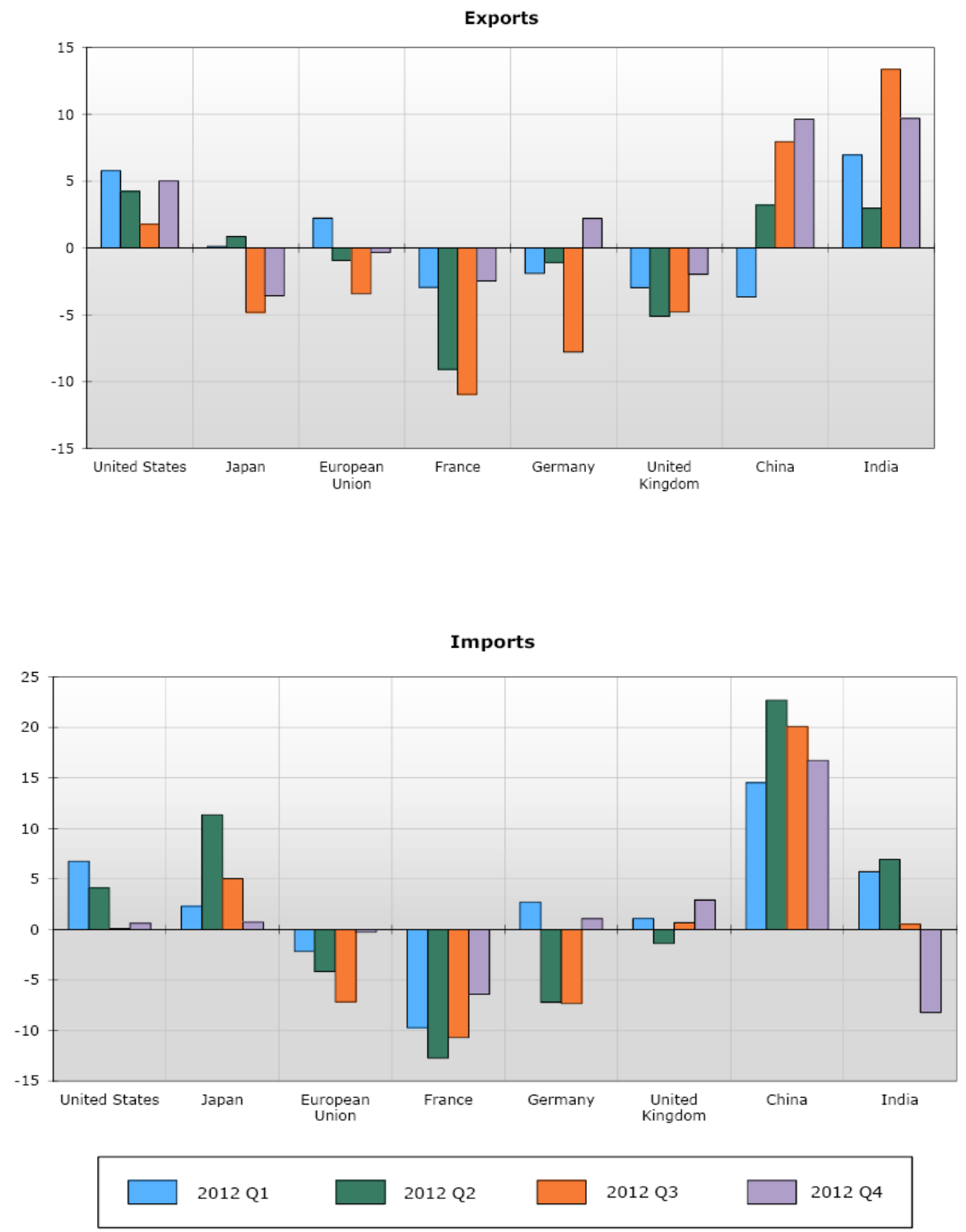

Chart 5. Commercial services exports and imports of selected economies, 2012Q1 - 2012Q4

Source: WTO Secretariat, 2013

Trends in the composition of trade shows that trade in services has grown faster than trade in goods over the last two decades (Krist, 2013). In this context important is how advances in information and communication technology have enabled a rapid expansion of services trade (Jackson, 2013) (Chart 5). This trend might in the future be spurred by rising energy costs. Moreover, the share of services in both manufacturing firms' inputs and outputs has increased. Digitalization and 3D printing are examples of the increasing grey zone between goods and services. Whether they are classified as one or the other is significant as different regulatory regimes might apply. With regard to natural resources, it shows that their price has increased and that the price of food products has become more volatile. Open question is how higher and more volatile agricultural commodity prices raise concerns regarding food security in developing countries (Eagleton-Pierce, 2013) and how this prices influence for the rise of global supply chains.

It can observe that comparable development has occurred in foreign direct investment. Inflows into developing countries and outflows from these countries now represent a major share of total foreign direct investment (FDI) (Jackson, 2013), and FDI between developing countries is rapidly expanding. Related to this development is the industrialization of developing countries and de-industrialization of developed countries which, once again, is closely interconnected with global supply chains. However, this growth is limited to only a few economies. It has caused 
greater differences among developing countries, with growing emerging economies and struggling least-developed countries (LDCs).

Distributional effects of trade play an important role in the broader socioeconomic context. It is important examines the extent to which the recent sharp increase in the unemployment rates of developed countries may be linked to trade and what this could mean for attitudes towards trade. While there is no conclusive evidence that trade contributes significantly to changes in long-run unemployment or in income inequality, public concerns about current levels of unemployment and income distribution in a number of countries are likely to have a bearing on trade policy-making.

Another ongoing trend is the increasing importance of consumer concerns (regarding the environment or food safety, for example) which has led to a proliferation of public policy measures that affect trade (WTO, 2012b). Global supply chains might exacerbate the issue when large firms impose private standards throughout their respective supply chains. A further trend is the fierce competition for scarce natural.

\subsection{The Political Economy of Trade and Countries Motivations for Bilateral Cooperating on Trade Policies}

The industrialization and spectacular growth of emerging economies, together with the fast expansion of services trade and of FDI, are inextricably related to the next intensive growth of production. The focus here will be on how the rise of global supply chains has had an impact on the political economy of trade and countries motivations for bilateral cooperating on trade policies (Jones, 2015). There is both theory and evidence suggesting that participation in global supply chains tends to strengthen anti-protectionist forces (Jones, 2015). The main impact, has been on unilateral tariff reductions (mostly among developing countries) and the proliferation of preferential trade agreements (PTAs) and bilateral investment treaties (Krist, 2013); (Jones, 2015); (Deudney, 2014). A considerable amount of trade opening has thus taken place outside the WTO.

The internationalization of supply chains was very important for fast economic development and industrialization of developing countries. Before the emergence of supply chains - and the information and communication technology (ICT) revolution that underpinned it - industrialization involved building a strong industrial base often behind the protection of tariffs and other NTMs (Jupill, Mattli, Snidal, 2013). The unbundling of global production made it possible for countries to industrialize by joining international supply chains (Jones, 2015). This process also changed the political economy of trade policy, creating in many developing countries a strong incentive to undertake unilateral tariff reductions.

There are three mechanisms through which production unbundling can lead to unilateral tariff reductions. First, the offshoring of production is likely to alter lobbying over trade policy in the host country. The relocation of production transforms importers of the products concerned into exporters. As a result, lobbying in favour of import tariffs on these goods decreases and pressure to reduce upstream tariffs increases. This effect, however, is more limited in cases where governments set up export processing zones to exploit the growing industrialization opportunities offered by supply chains (Jones, 2015). Secondly, a fall in coordination and communication costs may also have an impact on lobbying. With high trade costs, producers of final products may support infant industry protection of intermediate products if they believe that it could lower the price of domestically produced intermediate goods compared with imports. However, a fall in coordination and communication costs can break the coalition of interests behind high trade barriers, and lead downstream producers to lobby against tariffs on intermediate goods. Thirdly, offshoring improves the competitiveness of developed countries' products by reducing their costs, thus undermining import substitution strategies in developing countries (Jackson, 2013). Developing countries governments may either respond by lowering the tariffs on final goods, or, alternatively, by lowering upstream tariffs to improve the competitiveness of domestic final goods.

Empirical evidence seems to confirm that lobbying is indeed an important determinant of trade policy. In particular, there is evidence suggesting that supply chains can explain why the recent financial crisis did not lead to significant protectionism despite the fact that many countries had prudence in their applied tariffs, meaning they could raise them without violating their WTO commitments (Jones, 2015).

While unilateral tariff reductions have clearly been a positive step in the direction of more open trade, they may also have complicated multilateral, reciprocity based tariff reductions in the WTO. It must be underline that developing countries have already significantly reduced their applied tariffs, giving developed countries exporters less to fight for in multilateral negotiations (Jackson, 2013). Developed countries exporters also see less value in asking developing countries to commit to lower tariffs because they do not believe that developing countries governments have strong incentives to raise them (Jones, 2015).

Existing theoretical work suggests that a government's optimal tariff decreases when its constituents hold an ownership stake in a foreign market, leaving it with less incentive to manipulate the terms of trade (Krist 2013). 
Extending a terms of trade model of trade agreements to account for international ownership, shows that by eroding large countries' motives to improve terms of trade by raising tariffs, international ownership can also reduce their incentive to sign trade agreements. It must be emphasise that calculations of reciprocity in tariff negotiations should consider patterns of international ownership as well as trade flows.

Unilateral tariff reductions, in as much as they were not bound in the WTO, have tended to increase the level of prudence in developing countries' tariffs - i.e. the difference between the level at which tariffs are bound and the level at which they are applied - which has in turn complicated the Doha Development Agenda (DDA) non-agricultural market access negotiations (Jones, 2015). In the DDA's early days, discussion focused on the question of whether and how credit should be granted for autonomous trade opening (Mattoo and Olarreaga, 2001). Even when WTO members gave one's consent to negotiate reductions of their bound, rather than applied, tariff rates, the underlying problem did not disappear but merely reappeared under a different guise. Members started arguing about the value of reductions of bound rates that do not imply equivalent reductions of the corresponding applied rate.

In other cases, such as PTAs in Africa, tariffs are central to the bilateral agreements. Preferential tariffs raise several challenges. One concern, extensively discussed in the economic literature, on the systemic effects of preferential tariff reductions relates to the linkages between discriminatory and nondiscriminatory tariff reductions. A number of different mechanisms have been identified through PTAs (Krist, 2013; Jones, 2015).

\subsection{The Increasing Importance Bilateral Agreements in the Foreign Trade Policy}

Theoretical approaches that provide a rationale for trade agreements (Krist, 2013); (Jones, 2015) offer interesting insights into the impact of emerging new trading powers (Jackson, 2013). An early contribution in this area was made by Krasner (1976). He analyses the linkage between particular distributions of potential economic power, defined by the size and level of development of individual states, and the structure of the international trading system, defined in terms of openness. He argues that while a hegemonic system (in which one dominant player holds sway of smaller states) is likely to lead to an open trading system, a system composed of a few very large but unequally developed states is likely to lead to a closed structure (Kirshner, 2013). Since Krasner, however, the open economy politics literature has been largely silent on how the rise of emerging powers in the 21 st century is affecting international economic relations.

The fact that governments respond to the internationalization of supply chains by signing deep integration agreements at the regional level is broadly consistent with the limited amount of theory available on this topic (WTO, 2012b); (Jones, 2015). It is important to underline that, deep rather than shallow integration agreements and more individualized rules are needed to address the policy problems associated with the internationalization of supply chains (Antràs and Staiger, 2012). Countries intensively involved in supply chain trade may find it increasingly difficult to rely on broad GATT/WTO principles alone to address their trade-related problems, and may turn to more narrowly focused PTAs to achieve the deep and customized bargains they need (Jones, 2015).

An important result of the terms of trade theory (Krist, 2013) is that shallow integration, i.e. tariff commitments, can achieve internationally efficient policies (Bagwell and Staiger, 1999). However, Antràs and Staiger (2012) find that this result does not hold in the presence of offshoring and, more generally, when international prices are determined through bargaining. If producers are locked into trade relationships with foreign firms - and prices are set via bargaining - there are incentives to manipulate the markets of both the intermediate and the final product to shift the bargaining surplus. Governments might also try to pursue redistributive goals via a trading partner's policies.

Deep integration agreements are needed to resist these pressures. However, this in turn means that negotiations must cover a wider array of internal/domestic measures than are typically covered trade agreements (Krist, 2013). Thus, the rise of offshoring raises both a direct and an indirect challenge for the WTO (Jackson, 2013). It puts direct pressure on the WTO to evolve towards deeper integration and more individualized agreements. It also puts indirect pressure on the WTO to evolve in this direction, as member governments increasingly turn to PTAs to solve their trade-related problems.

It is interesting explore the effect of proliferating deep regional agreements on coherence in international trade governance (Jackson, 2013). The WTO suggested that new international trade rules are being negotiated and decided outside the WTO where power differences are greater and where the principles of non-discrimination and reciprocity are absent. It also argued that PTAs are here to stay. Governments will need to ensure that regional agreements and the multilateral trading system are complementary and that multilateral disciplines minimize any negative effects from PTAs (Krist, 2013). While the available literature suggests that deep integration rules are often non-discriminatory - for instance, provisions in the services or competition policy areas are often extended to non-members - certain provisions in regional agreements can contain discriminatory aspects that clash with the 
multilateral trading system. It has been shown that PTAs which make it more difficult to apply contingency measures to PTA partners may divert protectionist measures towards non-members (Prusa and Teh, 2010).

Deep provisions can also have a number of adverse systemic effects. For example, the important effects of regional regulatory harmonization can make it more difficult to multilateralize rules. PTAs may not include third-party most-favoured nation (MFN) clauses, thus effectively discriminating against other countries. Developed countries exporters may view bilateral and regional rather than multilateral agreements as faster and easier routes for achieving their objectives, further weakening the principle of non-discrimination.

With regard to services supply chains, some argue that their growth creates an additional need to re-examine and modernize current rules for services trade, as these rules were designed for a world where services were exported as final products from national firms, not a world where multiple firms supply stages of services production from multiple locations. Recent research on how differences in firms have an impact on trade policies reveals a related concern. Ciuriak et al. (2011) point at another difference between deep integration at the regional and at the multilateral level (Ciuriak et al., 2011). While heterogeneous firms trade models suggest that more importance should be granted to extensive than to intensive margin responses to trade opening, there is evidence suggesting that PTAs have positive effects at the intensive margin and negative effects at the extensive margin, whereas the opposite is true of opening in the multilateral context.

\section{Results and Findings}

During the rise of global supply chains the development of various firm models has made it possible to explore the effects of differences in firms on the political economy of trade. It must be undreline that trade opening has two opposing effects on domestic firms within the same industry. First, the cost of exporting decreases, which allows more firms to export and increases the sales of established exporters. Secondly, competition increases, which harms domestic firms. Which of these channels dominates for an individual firm depends on firm characteristics, such as size. As a result, lobbying competition arises not only between sectors but also within sectors in which some firms benefit and some lose due to trade. This effect might especially arise in the context of fixed costs because they rise entry costs and thereby shield existing producers or exporters from competition.

The least and most productive firms during the rise of global supply chains oppose more open trade when it comes to a reduction of NTMs because the competition effect outweighs the sales effect. It is the firms close to the export cut-off, i.e. those that just break even taking into account the costs of exporting, which benefit from trade opening and support it. This result we can use to explain a persistent feature of trade policy, namely the reluctance to accept opening trade in homogeneous goods and during the rise of a global supply chains. The emergence of supply chains exacerbates the issue and might weaken reciprocity in trade negotiations. It must be underline that as the largest firms are engaged in global production networks, they support NTMs to protect their foreign affiliates. The mechanism is similar to the one described above: multinational affiliates have fewer problems to overcome fixed exporting costs compared with less productive competitors.

In the conditions of the rise of global supply chains the large firms promote NTMs not only to reduce domestic competition but also to shield their foreign affiliates from export competition. One implication of the argument is that market access based rules of reciprocity might be insufficient to address the distributional effects of NTMs because reciprocal tariff concessions cannot account for them. Overall, these theoretical studies suggest that while the largest firms benefit from tariff reductions, they may not support the reduction of NTMs that have an effect on fixed costs. Large firms can more easily pay the sunk costs of adapting products to different specifications and benefit afterwards from less competition.

\section{Conclusion}

The harmonization of standards and rules on investment, intellectual property and services has become a standard part of new trade bilateral agreements. The differences among firms involved in trade are also important for the future development. The picture that arises from the trade is that even if many firms are indirectly involved in trade-related activities, only relatively few are exporting or importing and these firms tend to be larger and more productive than others. Such firms also have a role in technology advancement and the diffusion of know-how through supply chains.

It must be underline that if trade during the rise of global supply chains is perceived by a majority of voters as causing unemployment and/or increasing inequality, governments could refrain from pursuing further trade opening and may even be tempted by protectionism. Another possibility would be for governments to use more intensively public policies for protectionist purposes. With regard to trade negotiations, focusing exclusively on the efficiency effect of trade opening may no longer be possible. Distribution and labour-market effects will also need to be 
considered and accompanying measures may need to be proposed in order to win the support of a majority of voters for open trade by bilateral agreement especially in the conditions of the rise a global supply chains.

\section{References}

Antràs, P., \& Staiger, R.W. (2012). Trade Agreements and the Nature of Price Determination. American Economic Review Papers and Proceedings, 102(3), 470-476. https://doi.org/10.1257/aer.102.3.470

Bagwell, K., \& Staiger, R.W. (1999). Domestic Policies, National Sovereignty and International Economic Institutions. NBER Working Papers, 7293, National Bureau of Economic Research, Inc. https://doi.org/10.3386/w7293

Baldwin, R. (2012). WTO 2.0. Global governance of supply chain trade. Centre for Economic Policy Research, Policy Insight, No. 64, December.

Ciuriak, D., Lapham, B., Wolfe, R., Collins-Williams, T., \& Curtis, J. M. (2011). Firms in International Trade: Towards a New Trade Policy, November.

Deudney, D. (2014). Hegemony, nuclear weapons, and liberal hegemony. In G. J. Ikenberry (Ed.), Power, Order, and Change in World Politics. Cambridge University Press, Cambridge. https://doi.org/10.1017/CBO9781139680738.011

Eagleton-Pierce, M. (2013). Symbolic Power in the World Trade Organization, Oxford University Press, Oxford.

IMF International Financial Statistics. (2013). Global Trade Information Services GTA database, national statistics. Retrieved 24 October 2013, from http://www.wto.org/english/news_e/pres13_e/pr694_e.htm

Jackson, R.J. (2013). Global Politics in the $21^{\text {st }}$ Century. Cambridge University Press, New York.

Jones, K. (2015). Reconstructing the World Trade Organization for $21^{\text {st }}$ Century: An Institutional Approach. Oxford University Press, Oxford, New York. https://doi.org/10.1093/acprof:oso/9780199366040.001.0001

Jupill, W. M., \& Snidal, D. (2013). Institutional Choice and Global Commerce. Cambridge University Press, New York. https://doi.org/10.1017/CBO9781139855990

Kirshner, O. (2013). American Trade Politics and the Triumph of Globalism. Routledge Taylore\&Francis Group, New York and London.

Krasner, S.D. (1976). State Power and the Structure of International Trade. World Politics, 28, 317-347. https://doi.org/10.2307/2009974

Krist, W. (2013). Globalization and America's Trade Agreements, John Hopkins University Press, Baltimore.

Krugman, P. (1991). Increasing Returns and Economic Geography. Massachusetts Institute of Technology. https://doi.org/10.1086/261763

Kupchan, Ch. A. (2014). Unpacking hegemony: the social foundations of hierarchical order. In G. J. Ikenberry (Ed.), Power, Order, and Change in World Politics. Cambridge University Press, Cambridge. https://doi.org/10.1017/CBO9781139680738.003

Mattoo, A., \& Olarreaga, M. (2001). Should Credit Be Given for Autonomous Liberalization in Multilateral Trade Negotiation. CEPR Discussion Papers 2821.

Prusa, T.J., \& Teh, R. (2010). Protection Reduction and Diversion: PTAs and the Incidence of antidumping Disputes. NBER Working Papers 16276, National Bureau of Economic Research, Inc. https://doi.org/10.3386/w16276

The 2011 World Trade Report, WTO. (2011a).

The 2011 World Trade Report, WTO. (2011b).

The 2013 World TradeReport, WTO. (2013).

WT/TPR/OV/W/7. (2013).

WTO Secretariat. (2013). WTO Secretariat estimates, based on data compiled from IMF International Financial Statistics; Eurostat Comext Database; Global Trade Atlas; and national statistics.

WTO Secretariat. (2013).

\section{Note}

Note 1. Paper prepared in the framework of the Grant OPUS, Narodowe Centrum Nauki -NCN (National Centre of Science - NCS), Nr UMO - 2013/11/B/HS5/03572 